\title{
Phosphorus Utilization and Environmental and Economic Implications of Reducing Phosphorus Pollution from Ontario Dairy Cows ${ }^{1}$
}

\author{
E. Kebreab, ${ }^{*}{ }^{2}{ }^{2}$ N. E. Odongo, $\dagger$ B. W. McBride, $\dagger$ M. D. Hanigan, $\ddagger$ and J. France $†$ \\ *National Centre for Livestock and Environment, Department of Animal Science, University of Manitoba, Winnipeg, Manitoba, \\ R3T 2N2, Canada \\ †Centre for Nutrition Modelling, Department of Animal and Poultry Science, University of Guelph, Guelph, Ontario, N1G 2W1, Canada \\ ¥Department of Dairy Science, Virginia Polytechnic Institute and State University, Blacksburg 24061
}

\section{ABSTRACT}

A major source of environmental pollution has been overfeeding $\mathrm{P}$ to dairy cows, caused by the "safety margins" added to diets in order not to compromise the health and production of animals. An extant whole-animal model was evaluated using an experiment conducted in Ontario to assess its applicability for predicting $\mathrm{P}$ excretion. The objective of the study was to use the model to estimate $\mathrm{P}$ excretion levels and the economic and environmental implications of implementing mitigating options by following recommendations from studies that have reported sufficient levels of $\mathrm{P}$ inclusion in the diet. Mean square prediction error and concordance coefficient analysis showed that the overall predictions were close to the mean and that there was only a slight underprediction of fecal $\mathrm{P}$ output by the model. The majority of the error was random, with only $8.9 \%$ coming from error caused by deviation from the regression line, and the model did not show a systematic trend of overor underprediction. The model was then used to predict $\mathrm{P}$ excretion in Ontario by using diets commonly fed to dairy cows on Ontario farms. It is estimated that Ontario dairy farms produce $7 \mathrm{kt}$ of $\mathrm{P}$ annually at current levels of $\mathrm{P}$ inclusion in the diet. Reducing $\mathrm{P}$ levels from the current $0.41 \% \mathrm{P}$ of dry matter to $0.35 \%$ is estimated to save producers CAN $\$ 20 /$ cow per year and the environment $1.3 \mathrm{kt} / \mathrm{yr}$ without impairing cow health or productivity. Additionally, the reductions might be from inorganic $\mathrm{P}$ sources added to the feed, which are more polluting than organic sources because of their water-soluble nature and liability to leaching and runoff.

Key words: phosphorus, pollution, economics, dairy cow

Received June 11, 2007.

Accepted September 14, 2007.

${ }^{1}$ Supported by Dairy Farmers of Ontario and, in part, by the Canada Research Chairs Program.

${ }^{2}$ Corresponding author: kebreabe@cc.umanitoba.ca

\section{INTRODUCTION}

Globally, there has been an increase in public concern about environmental damage instigated by intensive animal feeding operations. This increased public concern has led some countries such as the Netherlands to introduce legislation (Jongbloed and Lenis, 1998). The provincial government of Ontario has also introduced nutrient management legislation to reduce nutrient output from farming operations, including intensive dairying, into the environment. For this reason, there is a greater need for dairy nutritionists to develop more efficient approaches toward diet formulation that result in minimal nutrient output to the environment.

Several surveys (e.g., Sansinena et al., 1999; Satter and Wu, 1999; Sink et al., 2000) have revealed that dairy producers in the United States feed 0.45 to $0.50 \%$ dietary $\mathrm{P}$. This is in excess of recommendations by NRC (2001) and in excess of the needs of lactating cows (Wu et al., 2001; Valk et al., 2002). The Canadian Food Inspection Agency (2007) recommends 0.30 and $1.3 \% \mathrm{P} / \mathrm{kg}$ of DM as minimum and maximum concentrations in feed for dairy cows, respectively. A reduction in dietary $\mathrm{P}$ to match the requirement of the cow more closely could result in 25 to $30 \%$ less fecal $\mathrm{P}$ and a savings of CAN $\$ 15$ to $\$ 20 /$ cow per year in $\mathrm{P}$ supplementation costs $(\mathrm{Wu}$ et al., 2000). However, some supplementation might be necessary if the desired $\mathrm{P}$ level cannot be achieved with commonly used feeds.

Phosphorus losses from livestock farms are primarily in the feces. Fecal $\mathrm{P}$ increases as dietary $\mathrm{P}$ increases (Morse et al., 1992; Wu et al., 2000; Odongo et al., 2007) and can account for significant $\mathrm{P}$ loading to bodies of surface water, depending on the watershed (Smith and Alexander, 2000). Increasing dietary $P$ levels with $P$ minerals not only leads to greater concentrations of total fecal $P$, but more importantly, increases the amount of water-soluble $\mathrm{P}$, which is most susceptible to loss into the environment (Dou et al., 2002). Recently, Odongo et al. (2007) suggested that the current forages grown in Ontario contain adequate amounts of $\mathrm{P}$ to sustain milk production in mature dairy cows without mineral $\mathrm{P}$ sup- 
plementation or without affecting animal productivity. From an environmental point of view, an efficient use of dietary $\mathrm{P}$ by dairy cows is important to minimize fecal $\mathrm{P}$ output and, as a result, $\mathrm{P}$ losses to the environment in quantities that exceed plant growth requirements.

The objectives of this study were therefore 1) to evaluate a dynamic $\mathrm{P}$ utilization model (Kebreab et al., 2004) by using P-balance experiment data, 2) to use the model to provide annual inventories of $\mathrm{P}$ excretion by dairy cows in Ontario, and 3) to make appropriate practical recommendations for sustainable reductions in the annual excretion of $\mathrm{P}$ associated with milk production.

\section{MATERIALS AND METHODS}

\section{P Balance Study}

Eight lactating multiparous Holstein dairy cows (108 \pm 8.0 DIM) at the Elora Dairy Research Centre, University of Guelph (Guelph, Ontario, Canada), were used in the study. The cows were blocked by parity and DIM and allocated to 1 of 2 treatments: 1 ) the regular Elora Dairy Research Centre milking cow TMR (a forage-toconcentrate ratio of 55:45; control; $0.42 \% \mathrm{P}$; Table 1) or 2) the milking cow TMR with no supplemental $\mathrm{P}$ (treatment; $0.35 \% \mathrm{P}$ ). Cows were fed ad libitum, allowing for 5 to $10 \%$ refusals. The TMR was offered twice daily at 0800 and $1300 \mathrm{~h}$, and the actual amount of feed offered and refused by individual animals was recorded daily to obtain net intake. Animals were cared for and handled in accordance with the Canadian Council on Animal Care regulations, and the University of Guelph Animal Care Committee reviewed and approved the experiment and all procedures carried out in the study. The animals had unlimited access to fresh water.

The cows were adapted to the treatments for $7 \mathrm{~d}$, followed by $5 \mathrm{~d}$ of total fecal collection as described by Plaizier et al. (2000). Briefly, total fecal collection was accomplished by positioning large steel trays over the gutter behind the cow in each stall. Every morning at $0900 \mathrm{~h}$, all feces was removed from each tray and transferred to large plastic bins. The feces was weighed and thoroughly mixed, and a subsample (approximately 1 $\mathrm{kg}$ ) was taken and stored at $-20^{\circ} \mathrm{C}$ for later $\mathrm{P}$ analysis. Urine was collected by using indwelling bladder catheters (26 Fr., 75 mL, CR Bard Inc., Covington, GA), using a modification of the method described by Crutchfield (1968); that is, leaving the catheter in place, unconnected from the collection tubing, for $24 \mathrm{~h}$ prior to collection, as described by Wright et al. (1998). Distilled water was used to inflate the catheter balloon. The urine was collected under acid conditions by adding $175 \mathrm{~mL}$ of concentrated sulfuric acid (Fisher Scientific, Fairlawn, NJ) to the empty polyethylene urine collection containers daily. A subsample of the urine (5\%) was taken each day for
Table 1. Ingredients and chemical composition (DM basis) of TMR used in the experiment

\begin{tabular}{|c|c|c|}
\hline \multirow[b]{2}{*}{ Item } & \multicolumn{2}{|c|}{$\begin{array}{c}\text { Dietary phosphorus, } \\
\% \text { of DM }\end{array}$} \\
\hline & 0.35 & 0.42 \\
\hline \multicolumn{3}{|l|}{ Ingredient composition, \% (DM basis) } \\
\hline Corn silage & 27.5 & 27.5 \\
\hline Alfalfa silage & 27.5 & 27.5 \\
\hline High-moisture corn & 30.0 & 30.0 \\
\hline Grain $\operatorname{mix}^{1}$ & 15.0 & $15.0^{2}$ \\
\hline \multicolumn{3}{|l|}{ Chemical composition, \% (DM basis) } \\
\hline $\mathrm{DM}, \%$ & 54.1 & 54.1 \\
\hline $\mathrm{CP}(\mathrm{N} \times 6.25)$ & 16.5 & 16.4 \\
\hline Soluble protein, \% & 4.8 & 4.4 \\
\hline Soluble protein, \% of CP & 28.8 & 26.8 \\
\hline Acid detergent protein, \% of CP & 8.8 & 9.1 \\
\hline Neutral detergent protein, $\%$ of $\mathrm{CP}$ & 29.4 & 30.0 \\
\hline Undegradable intake protein, $\%$ of $\mathrm{CP}$ & 35.8 & 36.6 \\
\hline $\mathrm{ADF}$ & 20.3 & 20.1 \\
\hline NDF & 34.0 & 33.5 \\
\hline Lignin, \% of NDF & 11.0 & 10.4 \\
\hline $\mathrm{NFC}^{3}$ & 38.2 & 38.6 \\
\hline Calcium & 0.79 & 0.79 \\
\hline Phosphorus & 0.35 & 0.42 \\
\hline Potassium & 1.41 & 1.39 \\
\hline Magnesium & 0.44 & 0.44 \\
\hline Sodium & 0.39 & 0.38 \\
\hline Fat & 3.95 & 4.15 \\
\hline Ash & 7.34 & 7.28 \\
\hline $\mathrm{NE}_{\mathrm{L}}, \mathrm{Mcal} / \mathrm{kg}$ & 1.55 & 1.57 \\
\hline
\end{tabular}

${ }^{1}$ Contained (\%, DM basis): soybean meal, 20; canola meal, 20 ; rolled roasted soybeans, 22; salt, 3 ; potassium chloride, 0.19 ; sodium bicarbonate, 2.9; distillers, 11.5; corn gluten meal, 12 ; trace vitamin premix (as fed: vitamin A, 12,500,000 IU per kg; vitamin D, 3,125,000 IU per kg; vitamin E, 45,000 IU per kg; Agribrands Purina Canada Inc., Woodstock, Ontario, Canada), 0.11; calcium carbonate, 4.18; magnesium oxide, 2.25; trace mineral premix (as fed: iron, 25,000 $\mathrm{mg} / \mathrm{kg}$; manganese, $95,450 \mathrm{mg} / \mathrm{kg}$; zinc, 95,450 mg/kg; copper, 23,850 $\mathrm{mg} / \mathrm{kg}$; cobalt, 1,625 mg/kg; iodine, $1,350 \mathrm{mg} / \mathrm{kg}$; selenium, $300 \mathrm{mg} /$ kg; Agribrands Purina Canada Inc.), 0.28.

${ }^{2} 1.65 \%$ dicalcium phosphate.

${ }^{3}$ Calculated as NFC $=100-(\% \mathrm{NDF}+\% \mathrm{CP}+\%$ fat $+\%$ ash $)$.

$\mathrm{P}$ analysis. Animals were administered $15 \mathrm{~mL}$ of Excenel (ceftiofur sodium sterile powder, Upjohn, Kalamazoo, MI) intramuscularly for $3 \mathrm{~d}$ following removal of the catheters.

The cows were milked in their stalls twice daily at 0600 and $1600 \mathrm{~h}$. Milk samples were collected from the morning milking, and one set of samples was preserved with 2-bromo-2-nitropropane-1-2-diol and immediately submitted to the Central Milk Testing Laboratory (Laboratory Services Division, University of Guelph) for compositional analysis. A second set of milk samples without preservative was stored at $-20^{\circ} \mathrm{C}$ for later $\mathrm{P}$ analysis. Blood samples were obtained daily via venipuncture of coccygeal vessels before the morning feeding into $7-\mathrm{mL}$ heparinized tubes (Becton Dickinson Vacutainer Systems, Franklin Lakes, NJ). Plasma was separated immediately by centrifugation at $2,500 \times g$ for $15 \mathrm{~min}$ at $4^{\circ} \mathrm{C}$ and stored at $-70^{\circ} \mathrm{C}$ for later $\mathrm{P}$ analysis. 


\section{Mechanistic Model}

The dynamic, mechanistic, whole-animal dairy cow model of Kebreab et al. (2004) was chosen because the model represents $\mathrm{P}$ flow in the dairy cow explicitly. The model was developed in Advanced Continuous Simulation Language by using the Model, Math, and Optimize features of the software (MGA Software, Concord, MA) with a Microsoft Visual Basic 6.0 front end. The model consists of 10 state variables representing $P$ pools in the rumen, small intestine, large intestine, blood, and saliva. The model simulates utilization of digestible $\mathrm{P}$ in the rumen; passage to the small intestine, where it is subject to absorption (represented by Michaelis-Menten saturation kinetics); and finally excretion via feces after further utilization by hind-gut microbes. Indigestible $\mathrm{P}$ is assumed to pass through the intestinal tract at the same rate as solid particles (Kebreab et al., 2004). This integrated model uses the rumen model of Dijkstra et al. (1992), which simulates microbial interactions in the rumen.

Inputs to the model included DMI and chemical feed constituents such as P, NDF, starch, CP, and degradabilities of $\mathrm{CP}, \mathrm{NDF}$, and starch. Outputs of the model included $\mathrm{P}$ in feces, urine, and milk.

\section{Statistical Analyses}

Observed and predicted fecal outputs were compared. Assessments of the error of prediction and source of error were made by calculating the mean square prediction error (MSPE):

$$
\mathrm{MSPE}=\sum_{i=1}^{n}\left(O_{i}-P_{i}\right)^{2} / n,
$$

where $n$ is the number of treatments, and $O_{i}$ and $P_{i}$ are the observed and predicted fecal outputs, respectively. The MSPE was decomposed into error caused by the overall bias of prediction, error caused by deviation of the regression slope from unity, and error caused by the disturbance (random variation; Bibby and Toutenburg, 1977). Root MSPE, expressed as a percentage of the supply, was used as a measure of the discrepancy between observed and predicted values.

The concordance correlation coefficient or reproducibility index (CCC; Lin, 1989) was also used to evaluate the precision and accuracy of observed vs. predicted fecal outputs. The CCC has been used in comparisons of chemical methods and assay evaluations, among others (Dhanoa et al., 1999). The CCC can be represented as a product of 2 components. The first component $(r)$ is the correlation coefficient estimate, which measures precision. This coefficient may vary from 0 to 1 , where 1 indicates perfect fit. The second component $\left(C_{b}\right)$ is the bias correction factor, which indicates how far the regression line deviates from the line of unity. This value also ranges from 0 to 1 , and 1 indicates that no deviation from the line of unity has occurred. Finally, the estimate $\mu$ measures location shift relative to the scale (difference of the means relative to the square root of the product of 2 standard deviations). This value ranges from -1 to 1 , with positive numbers indicating underprediction and negative numbers overprediction.

Simulation of P output was also conducted by using typical diets fed in Ontario, Canada. The composition of typical TMR fed to dairy cows in Ontario, based on the guidelines published by the Ontario Ministry of Agriculture and Food (2007), is shown in Table 2. To simulate an annual $\mathrm{P}$ excretion estimate, 3 diets corresponding to early-lactation, mid- to late-lactation, and dry-period feeding were used as inputs in the model. Predictions of $\mathrm{P}$ excretion were then made on a per animal basis, and an annual estimate was calculated by using the total number of cows. Statistics Canada (2007) estimated that there were 342,000 dairy cows in Ontario as of January 2007.

\section{RESULTS AND DISCUSSION}

\section{Evaluation of the Mechanistic Model}

The statistical analysis conducted suggested that the model gave accurate predictions. The MSPE showed that there was little deviation from the mean and that the majority of the error was random, with only $8.9 \%$ coming from error caused by deviation from the regression line (Table 3). The root MSPE also suggested that the level of accuracy was within $19 \%$ of the observed mean fecal $\mathrm{P}$ output. The residuals plot also confirmed that the error was mostly random and did not show a systematic trend (Figure 1).

Additionally, the CCC analysis showed that the overall predictions were close to the mean, and there was only a slight underprediction of fecal $\mathrm{P}$ output by the model. The bias correction factor was close to 1 , confirming that there was little bias in predictions of fecal $\mathrm{P}$ output by the model. Therefore, the model was accepted as one that can be used to predict $\mathrm{P}$ output from dairy cows raised under Northern American conditions.

\section{Simulation of $P$ Output}

Current Status. A 650-kg dairy cow producing 40 $\mathrm{kg}$ of milk/d consumes approximately $24.7 \mathrm{~kg} / \mathrm{d}$ of DM (Ontario Ministry of Agriculture and Food, 2007). This translates to an intake of $101.3 \mathrm{~g}$ of $\mathrm{P} / \mathrm{d}$, based on the values in Table 2 . In early lactation, DMI is reduced by approximately $18 \%$ because of reduced appetites (On- 
Table 2. Chemical composition of typical rations fed to dairy cows in Ontario, Canada ${ }^{1}$

\begin{tabular}{|c|c|c|c|}
\hline Item & $\begin{array}{l}\text { Early lactation } \\
\quad(0 \text { to } 3 \mathrm{wk})\end{array}$ & $\begin{array}{l}\text { Milk production } \\
\quad(40 \mathrm{~kg} / \mathrm{d})\end{array}$ & Dry period \\
\hline \multicolumn{4}{|l|}{ Protein } \\
\hline $\mathrm{CP}, \%$ & 19 & 17 & 12 \\
\hline Degradable intake protein, \% of CP & 55 & 60 & - \\
\hline Undegradable intake protein, \% of CP & 45 & 40 & - \\
\hline \multicolumn{4}{|l|}{ Energy } \\
\hline Net energy intake, Mcal/kg & 1.67 & 1.72 & 1.25 \\
\hline Total digestible nutrients, $\%$ of $\mathrm{DM}$ & 73 & 75 & 56 \\
\hline \multicolumn{4}{|l|}{ Fiber } \\
\hline Crude fiber, \% & 17 & 15 & 22 \\
\hline $\mathrm{ADF}, \%$ & 21 & 19 & 27 \\
\hline NDF, \% & 28 & 25 & 35 \\
\hline \multicolumn{4}{|l|}{ Minerals } \\
\hline Calcium, \% & 0.77 & 0.64 & 0.39 \\
\hline Phosphorus, \% & 0.48 & 0.41 & 0.24 \\
\hline Potassium, \% & 1.0 & 1.0 & 0.65 \\
\hline Magnesium, \% & 0.25 & 0.25 & 0.2 \\
\hline Sulfur, \% & 0.2 & 0.2 & 0.16 \\
\hline Sodium, \% & 0.18 & 0.18 & 0.1 \\
\hline Chlorine, \% & 0.25 & 0.25 & 0.2 \\
\hline Manganese, ppm & 40 & 40 & 40 \\
\hline Copper, ppm & 10 & 10 & 10 \\
\hline Zinc, ppm & 40 & 40 & 40 \\
\hline Iron, ppm & 50 & 50 & 50 \\
\hline Cobalt, ppm & 0.1 & 0.1 & 0.1 \\
\hline Iodine, $\mathrm{ppm}$ & 0.6 & 0.6 & 0.6 \\
\hline \multicolumn{4}{|l|}{ Vitamins, lU/kg } \\
\hline Vitamin A & 4,000 & 3,200 & 4,000 \\
\hline Vitamin D & 1,000 & 1,000 & 1,200 \\
\hline Vitamin E & 15 & 15 & 15 \\
\hline
\end{tabular}

${ }^{1}$ Guidelines for feeding dairy cows in Ontario, Canada. Available at http://www.omafra.gov.on.ca/english/ livestock/dairy/facts/pub101.htm (accessed April 19, 2007).

tario Ministry of Agriculture and Food, 2007); therefore, $\mathrm{P}$ intake was assumed to be $85.4 \mathrm{~g} / \mathrm{d}$ for the first $3 \mathrm{wk}$ after parturition. Similar reductions in $\mathrm{P}$ intake during the first few weeks of lactation were reported by $\mathrm{Wu}$ et al. (2000). The dry cows were expected to consume approximately $2 \%$ of their BW in DM, so $13 \mathrm{~kg} / \mathrm{d}$ of DMI and an intake $31.2 \mathrm{~g} / \mathrm{d}$ of $\mathrm{P}$ were assumed as model inputs. The model predicted that the cows would excrete $50.3,65.6$, and $17.0 \mathrm{~g}$ of $\mathrm{P} / \mathrm{d}$, in early and midlactation and the dry period, respectively. These predictions are close to the estimates of Wu et al. (2000), who reported $\mathrm{P}$ excretion of $54.0 \mathrm{~g}$ of $\mathrm{P} / \mathrm{d}$ from cows fed $24 \mathrm{~kg}$ of DM/ $\mathrm{d}(0.40 \%$ dietary $\mathrm{P}$ intake) and producing $45 \mathrm{~kg}$ of milk/ $\mathrm{d}$. The $\mathrm{P}$ excretion from dry cows was mainly composed of inevitable losses because of unavailability, $\mathrm{P}$ bound in microbial nucleic acid and that passed from the large intestine to feces, and other endogenous sources. On an annual basis, the total $\mathrm{P}$ excretion (from early lactation

Table 3. Comparison of model performance using data from dairy cows fed high- or low-P diet

\begin{tabular}{lcccc}
\hline \multicolumn{5}{c}{ Mean square prediction error $(\mathrm{MSPE})^{1}$} \\
\hline RMSPE, g/d & \%RMSPE & ECT, \% & ER, \% & ED, \% \\
\hline 9.63 & 19.2 & 0.001 & 8.88 & \\
& Concordance correlation coefficient $(\mathrm{CCC})^{2}$ & & \\
\hline CCC & $r$ & $C_{b}$ & $\mu$ & \\
\hline 0.40 & 0.42 & 0.95 & 0.0014 & \\
\hline
\end{tabular}

${ }^{1} \mathrm{RMSPE}=$ root MSPE $(\mathrm{g} / \mathrm{d}) ; \%$ RMSPE = RMPSE as a percentage of the mean of observed fecal output; ECT $=$ MSPE decomposed into error because of overall bias of prediction; ER = error caused by deviation of the regression slope from unity; ED = error caused by the disturbance or random variation.

${ }^{2} r$ = correlation coefficient estimate; $C_{b}=$ bias correction factor; $\mu=$ location shift relative to the scale (squared difference of the means relative to the product of $2 \mathrm{SD}$ ). 


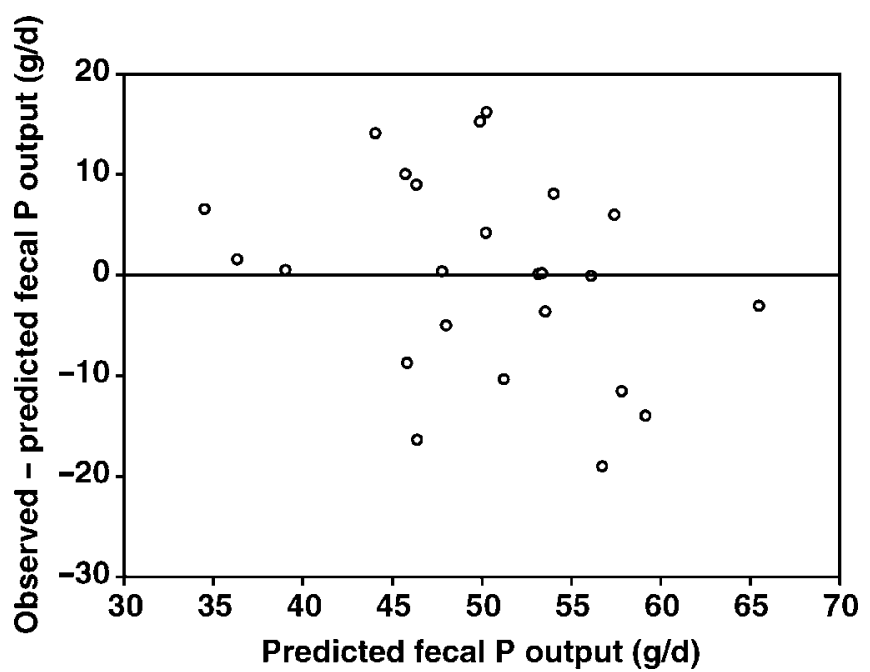

Figure 1. Residual plots of fecal $\mathrm{P}$ outputs predicted by the model of Kebreab et al. (2004), using data from Odongo et al. (2007).

to the dry period) is calculated to be $20.5 \mathrm{~kg}$ of $\mathrm{P} /$ cow or a total of $7.0 \mathrm{kt}$ of $\mathrm{P}$ excreted on Ontario dairy farms.

Mitigating Options. The $\mathrm{P}$ balance of cows is determined by $\mathrm{P}$ intake, intestinal absorption of $\mathrm{P}$, and secretion of $\mathrm{P}$ in milk. Intestinal absorption of $\mathrm{P}$ depends on solubility and $\mathrm{pH}$, and is highest for inorganic $\mathrm{P}$ supplements (Kebreab and Vitti, 2005). The concentration of $\mathrm{P}$ in milk is rather constant $(0.9 \mathrm{~g} / \mathrm{kg})$, and $\mathrm{P}$ excretion in milk depends largely on the milk production level. Therefore, mitigation options are focused on reducing fecal $\mathrm{P}$. These include reducing total $\mathrm{P}$ in the diet and manipulating the type of $\mathrm{P}$ excreted in feces.

Reducing Dietary $P$. Reducing the amount of $\mathrm{P}$ included in dairy cow rations is one of the most effective ways to cut $\mathrm{P}$ excretion. However, concern over the health and fertility of cows fed deficient amounts of $\mathrm{P}$ has led to higher than necessary amounts in animal feed. Realizing this concern, Wu et al. (2001) studied the effects of reducing $\mathrm{P}$ consumption from 0.47 to $0.31 \% \mathrm{P}$ in the DM over 2 to 3 lactations. The authors reported that there was no difference in milk production and bone $\mathrm{P}$ density between cows fed $0.47,0.39$, and $0.31 \% \mathrm{P}$. Although $0.31 \%$ was found to be borderline deficient, dietary $\mathrm{P}$ at $0.39 \%$ did not affect bone $\mathrm{P}$ content or strength. Therefore, predictions were made with the model assuming $0.39 \% \mathrm{P}$ in the diet for lactating cows (after $3 \mathrm{wk}$ ). A reduction of just $0.02 \% \mathrm{P}$ in the diet can result in a savings of $620 \mathrm{t}$ of $\mathrm{P} / \mathrm{yr}$, which is nearly enough to meet the $\mathrm{P}$ requirement of dairy cows in Ontario for the entire dry period. Tallam et al. (2005) showed that a further reduction of the $\mathrm{P}$ level to $0.35 \%$ of $\mathrm{DM}$ did not affect postpartum ovarian activity, reproductive performance, or milk production. Reduction of $\mathrm{P}$ to $0.35 \%$

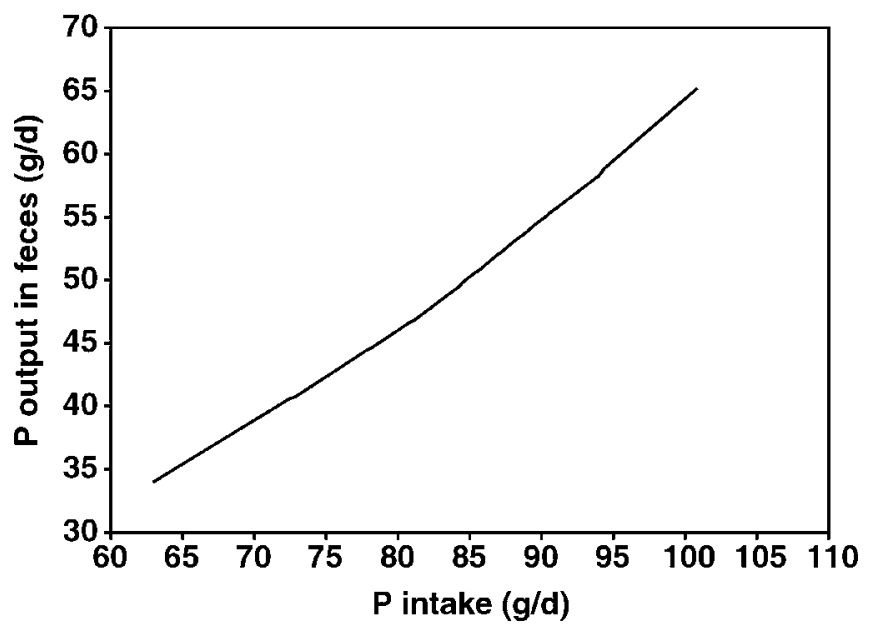

Figure 2. Graphical representation of fecal $\mathrm{P}$ output predicted by the model of Kebreab et al. (2004) as P intake increases in a dairy cow assuming $24.7 \mathrm{~kg}$ of DM/d intake and producing $40 \mathrm{~kg}$ of milk/d.

of $\mathrm{DM}$ would decrease annual $\mathrm{P}$ excretion by dairy cows in Ontario by $1.3 \mathrm{kt}$. Valk et al. (2002) have suggested that much lower amounts of $\mathrm{P}(0.26$ to $0.29 \% \mathrm{P}$ in $\mathrm{DM})$ are sufficient to meet the cow's requirement. However, the cows in the Valk et al. (2002) experiment had an average annual milk production of approximately 9,000 $\mathrm{kg}$. A reduction of $\mathrm{P}$ in the diet from 0.41 to $0.35 \%$ during mid to late lactation would therefore save Ontario producers approximately CAN $\$ 20 /$ cow per year. This calculation is based on assuming all cost savings are from reduced inorganic $\mathrm{P}$ supplementation at a cost of CAN $\$ 4.9 / \mathrm{kg}$ of $\mathrm{P}$. However, if feeds low in $\mathrm{P}$ are used, such as distillers grains, some supplementation might be necessary to meet the $\mathrm{P}$ requirement.

Figure 2 shows predicted $\mathrm{P}$ output as $\mathrm{P}$ intake increases. A large proportion of the $\mathrm{P}$ intake above the requirement of the animal is excreted mainly in feces. The model predictions are in agreement with observed data (e.g., Wu et al., 2000) in suggesting that once the cows take up $\mathrm{P}$ for milk, microbial synthesis, maintenance, and bone deposition, the unutilized $\mathrm{P}$ is excreted via feces, and at higher amounts via urine. Odongo et al. (2007) reported that although the total amount of $\mathrm{P}$ excreted in urine was negligible, at 0.42 vs. $0.35 \%$ dietary $\mathrm{P}(85.6$ vs. $67.4 \pm 5.00 \mathrm{mg} / \mathrm{d}$ for a $0.42 \% \mathrm{P}$ diet vs. a $0.35 \% \mathrm{P}$ diet, respectively), significantly lower urinary $\mathrm{P}$ was excreted for the $0.35 \% \mathrm{P}$ diet.

Type of P Excreted. Dietary P occurs in inorganic and organic compounds with varying degrees of solubility. Fecal $\mathrm{P}$ also consists of inorganic and organic $\mathrm{P}$, with the former being readily available for plant and algal growth in surface waters. Kebreab et al. (2005) observed that the type of $\mathrm{P}$ changes as it moves along the digestive tract of the ruminant as significant amounts of $\mathrm{P}$ are 
added into the gut via saliva. It is argued that information on the solubility of fecal $\mathrm{P}$ derived from different diets may assist attempts to reduce environmental pollution from dairy herds. Toor et al. (2005) observed that $64 \%$ of ingested $\mathrm{P}$ was excreted in feces as inorganic $\mathrm{P}$, which is comparable with the figure of up to $70 \%$ reported by Dou et al. (2000). Phytic acid in feces was $18 \%$ and the rest was of microbial origin (Toor et al., 2005). Although inclusion of phytases might improve phytic acid digestibility, more focus needs to be given to reducing the inorganic part of $\mathrm{P}$ in feces through diet manipulation. For example, Dou et al. (2001) showed that reducing dietary $\mathrm{P}$ decreased the water-soluble fraction of fecal P significantly. Therefore, reducing inorganic $\mathrm{P}$ supplementation will not only decrease the total amount of $\mathrm{P}$ excreted but also the potentially more polluting watersoluble P.

Currently, the Canadian Food Inspection Agency (2007) allows $\mathrm{P}$ in diets of up to $1.3 \%$, and there is no legislation to limit the amount of $\mathrm{P}$ included in the diet to environmentally acceptable levels. Several studies have shown that current levels are too high and need to be reduced. The model has shown that mitigation options have environmental and economic advantages.

\section{CONCLUSIONS}

Predictions of $\mathrm{P}$ excretion using the whole-animal model of Kebreab et al. (2004) were close to observed values from experiments conducted in Ontario. When typical dairy cow diets were used as inputs, predictions of the model showed that producers could save up to CAN $\$ 20 /$ cow per year by feeding $0.35 \% \mathrm{P}$, which, in many cases, means not supplementing the diet with inorganic $\mathrm{P}$ sources. The reduction would also reduce $\mathrm{P}$ excretions from dairy cow operations by $1.3 \mathrm{kt} / \mathrm{yr}$.

\section{REFERENCES}

Bibby, J., and H. Toutenburg. 1977. Prediction and Improved Estimation in Linear Models. John Wiley \& Sons, London, UK.

Canadian Food Inspection Agency. 2007. Livestock Feeds. Schedule 5 (Table 4). http://www.inspection.gc.ca/english/anima/feebet/ feebete.shtml Accessed March 5, 2007.

Crutchfield, W. O. 1968. A technique for the placement of an indwelling catheter in the cow. Vet. Med. Small Anim. Clin. 63:1141-1144.

Dhanoa, M. S., S. J. Lister, J. France, and R. L. Barnes. 1999. Use of mean square prediction error analysis and reproducibility measures to study near infrared calibration equation performance. J. Near Infrared Spectrosc. 7:133-143.

Dijkstra, J., H. D. St, C. Neal, D. E. Beever, and J. France. 1992. Simulation of nutrient digestion, absorption and outflow in the rumen: Model description. J. Nutr. 122:2239-2256.

Dou, Z., K. F. Knowlton, R. A. Kohn, Z. Wu, L. D. Satter, G. Zhang, J. D. Toth, and J. D. Ferguson. 2002. Phosphorus characteristics of dairy feces affected by diets. J. Environ. Qual. 31:2058-2065.

Dou, Z., K. Knowlton, G. Zhang, Z. Wu, and R. Kohn. 2001. Lowering dietary $\mathrm{P}$ in dairy rations reduces the vulnerable $\mathrm{P}$ fraction in manure. J. Dairy Sci. 84(Suppl. 1):254. (Abstr.)
Dou, Z., J. D. Toth, D. T. Galligan, C. F. Ramberg, and J. D. Ferguson. 2000. Laboratory procedures for characterizing manure phosphorus. J. Environ. Qual. 29:508-514.

Jongbloed, A. W., and N. P. Lenis. 1998. Environmental concerns about animal manure. J. Anim. Sci. 76:2641-2648.

Kebreab, E., J. A. N. Mills, L. A. Crompton, A. Bannink, J. Dijkstra, W. J. J. Gerrits, and J. France. 2004. An integrated mathematical model to evaluate nutrient partition in dairy cattle between animal and environment. Anim. Feed Sci. Technol. 112:131-154.

Kebreab, E., M. A. Shah, D. E. Beever, D. J. Humphries, J. D. Sutton, J. France, and I. Mueller-Harvey. 2005. Effects of contrasting forage diets on phosphorus utilisation in lactating dairy cows. Livest. Prod. Sci. 93:125-135.

Kebreab, E., and D. M. S. S. Vitti. 2005. Mineral metabolism. Pages 469-486 in Quantitative Aspects of Ruminant Digestion and Metabolism. 2nd ed. J. Dijkstra, J. M. Forbes, and J. France, ed. CAB Int., Wallingford, UK.

Lin, L. I. K. 1989. A concordance correlation coefficient to evaluate reproducibility. Biometrics 45:255-268.

Morse, D., H. H. Head, C. J. Wilcox, H. H. Van Horn, C. D. Hissem, and B. Harris. 1992. Effects of concentration of dietary phosphorus on amount and route of excretion. J. Dairy Sci. 75:3039-3049.

NRC. 2001. Nutrient Requirements of Dairy Cattle. 7th. rev. ed. Natl. Acad. Sci., Washington, DC.

Odongo, N. E., D. McKnight, A. Koekkoek, J. W. Fisher, P. Sharpe, E. Kebreab, J. France, and B. W. McBride. 2007. Reducing the potential for phosphorus pollution from intensive dairy operations into the environment. Can. J. Anim. Sci. (accepted)

Ontario Ministry of Agriculture and Food. 2007. Factsheet: Guidelines for feeding dairy cows. http://www.omafra.gov.on.ca/english/livestock/dairy/facts/pub101.htm Accessed Apr. 19, 2007.

Plaizier, J. C., A. Martin, T. Duffield, R. Bagg, P. Dick, and B. W. McBride. 2000. Effect of a prepartum administration of monensin in a controlled-release capsule on apparent digestibilities and nitrogen utilization in transition dairy cows. J. Dairy Sci. 83:2918-2925.

Sansinena, M., L. D. Bunting, S. R. Stokes, and E. R. Jordan. 1999. A survey of trends and rationales for phosphorus recommendations among Mid-South nutritionists. Pages 51-54 in Proc. Mid-South Rumin. Nutr. Conf., Dallas, TX. Texas Agric. Ext. Serv., Dallas.

Satter, L. D., and Z. Wu. 1999. New strategies in ruminant nutrition. Pages 1-24 in Proc. Southwest Nutr. Manage. Conf., Phoenix, AZ. Univ. Arizona, Tucson.

Sink, S. E., K. F. Knowlton, and J. H. Herbein. 2000. Economic and environmental implications of overfeeding phosphorus on Virginia dairy farms. J. Anim. Sci. 78(Suppl. 2):4. (Abstr.)

Smith, R. A., and R. B. Alexander. 2000. Sources of nutrients in the nation's watersheds. Page 13-21 in Proc. Managing Nutr. and Pathogens from Anim. Agric., Camp Hill, PA. Natural Resource, Agriculture, and Engineering Service, Ithaca, NY.

Statistics Canada. 2007. Table 1-8. Cattle on Farms-Ontario. http:// www.statcan.ca/english/freepub/23-012-XIE/2006002/ t056_en.htm Accessed Apr. 19, 2007.

Tallam, S. K., A. D. Ealy, K. A. Bryan, and Z. Wu. 2005. Ovarian activity and reproductive performance of dairy cows fed different amounts of phosphorus. J. Dairy Sci. 88:3609-3618.

Toor, G. S., B. J. Cade-Menun, and J. T. Sims. 2005. Establishing a linkage between phosphorus forms in dairy diets, feces, and manures. J. Environ. Qual. 34:1380-1391.

Valk, H., L. B. J. Sebek, and A. C. Beyen. 2002. Influence of phosphorus intake on excretion and blood plasma and saliva concentrations of phosphorus in dairy cows J. Dairy Sci. 85:2642-2649.

Wright, T. C., S. Moscardini, P. H. Luimes, P. Susmel, and B. W. McBride. 1998. Effects of rumen-undegradable protein and feed intake on nitrogen balance and milk protein production in dairy cows. J. Dairy Sci. 81:784-793.

Wu, Z., L. D. Satter, A. J. Blohowiak, R. H. Stauffacher, and J. H. Wilson. 2001. Milk production, estimated phosphorus excretion, and bone characteristics of dairy cows fed different amounts of phosphorus for two or three years. J. Dairy Sci. 84:1738-1748.

Wu, Z., L. D. Satter, and R. Sojo. 2000. Milk production, reproductive performance, and fecal excretion of phosphorus by dairy cows fed three amounts of phosphorus. J. Dairy Sci. 83:1028-1041. 